\title{
URZĄD REKTORA SANKTUARIUM
}

Treść: Wstęp. - 1. Pojęcie i konieczność istnienia urzędu rektora sanktuarium. 2. Kwalifikacje kustosza i jego formacja. - 3. Zadania rektora sanktuarium. Wnioski

\section{Wstęp}

Prefekt Kongregacji ds. Duchowieństwa kard. Mauro Piacenza w Liście do rektorów sanktuariów z 2011 r. pisał: „pragnę zwrócić się do każdego z Was z moim życzliwym pozdrowieniem, które to chętnie kieruję również do wszystkich, którzy wraz z wami pracują duszpastersko w Sanktuariach, załączając wyrazy mojego szczerego podziękowania za troskliwe poświęcanie się każdego dnia potrzebom duszpasterskim pielgrzymów, którzy z każdego zakątka świata licznie przybywają do miejsc kultu Wam powierzonych"1.

Wierni pielgrzymują do sanktuarium ,by wielbić Ojca, wyznawać swoją wiarę, pojednać się z Bogiem, z Kościołem i z bliźnimi oraz błagać o wstawiennictwo Matkę Bożą lub świętego"2. Pobudzani szczególną przyczyną pobożności pielgrzymi udają się jakiegoś kościoła lub innego miejsca świętego, gdzie spodziewają się bliższego spotkania z Bogiem i otrzymania upragnionych łask. Ze swej strony, po odpo-

${ }^{1}$ Lettera della Congregazione del Clero ai Rettori dei Santuari (15 agosto 2011), Introduzione, Città del Vaticano 2011, tekst polski: KongregaCJA DS. Duchowieństwa, List do kustoszy sanktuariów (15 sierpnia 2011), Anamnesis 17(2011) nr 4, s. 19-25.

2 Congregatio de Cultu Divino et Disciplina Sacramentorum, Direttorio su pietà popolare e liturgia. Principi e orientamenti (17 decembris 2001), nr 264, Città del Vaticano 2002, tekst polski: Kongregacja Kultu Bożego i Dyscypliny SaKramentów, Dyrektorium o pobożności ludowej i liturgii. Zasady $i$ wskazania (17 grudnia 2001), Poznań 2003, (odtąd: DPL). 
wiednim rozważeniu sprawy, kompetentna władza kościelna nie tylko aprobuje ich akty pobożności i jeśli zdają się zalecać okoliczności miejsca, napływ pielgrzymów a zwłaszcza dobro wiernych przyznaje pewne przywileje, ale nadto ustanawia specjalne duszpasterstwo, które zobowiązuje tytulariuszy sanktuarium do podjęcia intensywniejszych posług na rzecz przybywających pielgrzymów³ . „Od kierujących sanktuariami wymaga się bowiem zaspokajania specyficznych i różnorakich oczekiwań przybywających tam wiernych"4. Sanktuarium ma zatem cel sensu stricto duszpasterski, a w organizacji duszpasterstwa sanktuaryjnego zasadniczą rolę spełnia rektor (kustosz) i współpracownicy, którzy są ,prawdziwymi filarami duszpasterskiego oddziaływania sanktuariów"s.

Niniejszy artykuł podejmuje kwestię urzędu rektora sanktuarium w świetle obowiązujących przepisów.

\section{Pojęcie i konieczność istnienia urzędu rektora sanktuarium}

O rektorze sanktuarium Kodeks Prawa Kanonicznego z 1983 r. wypowiada się tylko jeden raz, mianowicie w kan. 1232 2, gdzie poleca, aby w statutach określić m.in. władzę rektora. O urzędzie rektora traktują także inne dokumenty prawne. Autorzy Dyrektorium o pobożności ludowej i liturgii przypominają, że ,adresatami [tego] dokumentu są (...) przede wszystkim rektorzy sanktuariów". Wspomniane Dyrektorium mówi o "odpowiedzialnych za sanktuaria"7 i duszpasterstwo sanktuaryjne ${ }^{8}$, wzywa rektorów sanktuariów, aby, jeśli to możliwe, starali się do programu pielgrzymek włączyć godną i uroczystą celebrację

3 Por. M. Ostrowski, Sanktuarium w teologiczno-duszpasterskiej perspektywie, [w:] Zawierzenie Bożemu Miłosierdziu w łagiewnickim sanktuarium. Materiały z sympozjum, pod red. J. Machniaka, Kraków 2003, s. 44.

${ }^{4}$ Komisja Konferencu Episkopatu WŁoch ds. Duszpasterstwa czasu wolnego, tuRYSTYKI I SPORTU, Pielgrzymowanie u progu trzeciego tysiąclecia, (29 czerwca 1998), nr 30, Salvatoris Mater 1(1999), nr 4, s. 311-335.

5 Tamże, nr 31.

6 DPL, nr 5.

7 Tamże, nr 266.

8 Por. tamże, nr 288. 
[liturgii] godzin ${ }^{9}$, aby troszczyli się o właściwe udzielanie błogosławieńst $w^{10}$, pomagali pielgrzymom w uświadomieniu sobie „ekumenizmu duchowego" 11 .

$\mathrm{Na}$ temat rektorów sanktuarium zamieszczają wzmianki także Wskazania i propozycje obchodu Roku Maryjnego. Prawodawca domaga się od nich troski o stały rozwój życia liturgicznego ${ }^{12}$ i o jego wzorcowe wykonywanie ${ }^{13}$, o wzorowe pełnienie w sanktuarium dzieł miłosierdzia ${ }^{14} \mathrm{i}$ zgodne z prawem udzielanie sakramentaliów ${ }^{15}$.

Rektorów sanktuariów ma na uwadze także Dyrektorium o pasterskiej postudze biskupów ,Apostolorum Successores”. Redaktorzy piszą, że ,jest bowiem zadaniem biskupów, z pomocą ich bezpośrednich współpracowników, a zwłaszcza rektorów sanktuariów, ustalić zasady i podać praktyczne wskazówki, uwzględniając lokalne tradycje i szczególne formy pobożności ludowej”"16.

$\mathrm{Na}$ temat rektorów sanktuariów wypowiada się dekret dotyczący odprawiania mszy świętych ,wielointencyjnych” lub kumulatywnych Mos iugiter, gdzie czytamy, że „zwłaszcza w Sanktuariach oraz w innych miejscach pobożnych, do których wierni licznie pielgrzymują i zwykli więcej zamawiać Mszy świętych, rektorzy są zobowiązani w sumieniu czuwać nad tym, by dokładnie były przestrzegane normy

9 Por. tamże, nr 271.

${ }^{10}$ Por. tamże, nr 272-273.

${ }^{11}$ Por. tamże, nr 277.

${ }^{12}$ Congregazione Per Il Culto Divino, Orientamenti e proposte per la celebrazione dell'anno mariano, (3 aprile 1987), nr 74, Notitiae 23(1987), nr 251, s. 342-396, tekst polski: Kongregacja Kultu Bożego, Wskazania i propozycje obchodu Roku Maryjnego, Wiadomości Urzędowe Diecezji Opolskiej 43(1988), nr 1-2, s. 53-94, (odtąd: OPCM).

${ }^{13}$ Por. tamże, nr 75.

${ }^{14}$ Por. tamże, nr 76.

${ }^{15}$ Por. tamże, nr 83.

${ }^{16}$ Congregaticio pro Episcopis, Direttorio per il ministero pastorale dei vescovi „Apostolorum Successores” (22 febbraio 2004), nr 153, Città del Vaticano 2004, tekst polski: Kongregacja do sPRAW BISKuPÓw, Dyrektorium o pasterskiej postudze biskupów „Apostolorum Successores” (22 lutego 2004), Kielce 2005, (odtąd: AS). 
ustanowione w tej materii prawem powszechnym (por. zwłaszcza kan. 945-956) oraz niniejszym dekretem"17.

Wreszcie litterae apostolicae motu proprio Misericordia Dei wspomina o rektorach sanktuariów, kiedy obliguje ich do okresowego sprawdzania, „czy faktycznie wierni mają możliwie najbardziej ułatwiony dostęp do spowiedzi"18.

Gdy idzie o nazwę urzędu, poprzez który uprawnieni duchowni kierują sanktuariami, to obowiązujący Kodeks używa nazwy rektor sanktuarium $^{19}$. Rektor (-oris) z języka łacińskiego znaczy kierownik, rządca, przełożony ${ }^{20}$. Wspomniany duchowny jest także nazywany kustoszem. Custos znaczy: stróż, obrońca ${ }^{21}$. Autorzy Dyrektorium o pobożności ludowej $i$ liturgii mówią o kustoszach sanktuariów w następującym tekście: „biskupi i kustosze sanktuariów powinni dbać o to, aby reprodukowane do użytku wiernych święte obrazy, umieszczane w domach lub noszone przez nich, nie były banalne i nie wprowadzały w błąd"22. Także wiele dokumentów prawa partykularnego nazywa rektora kustoszem. Dokument Komisji Konferencji Episkopatu Włoch ds. Duszpasterstwa czasu wolnego, turystyki i sportu Pielgrzymowanie u progu trzeciego tysiąclecia zawiera następujący zapis: „kustosze

${ }^{17}$ Congregazione per il Clero, Decreto Mos iugiter (22 febbraio 1991), art. 4, Acta Apostolicae Sedis 83(1991), s. 443-446, tekst polski: Kongregacja DS. DuchowieńSTWA, Dekret dotyczący odprawiania mszy świętych ,wielointencyjnych” lub kumulatywnych Mos iugiter (22 lutego 1991), Częstochowskie Wiadomości Archidiecezjalne 66(1992), nr 1-3, s. 1-4.

${ }^{18}$ JoAnnes Paulus P.P. II, Litterae apostolicae motu proprio Misericordia Dei quibus de sacramenti paenitentiae celebratione quaedam rationes explicantur (7 aprilis 2002), nr 2, Acta Apostolicae Sedis 94(2002), s. 452-459, tekst polski: L'Osservatore Romano, wydanie polskie, 23(2002), nr 6, s. 4-7.

${ }^{19}$ Kan. $1232 \$ 2$.

${ }^{20}$ A. Jougan, Słownik kościelny łacińsko-polski, Warszawa 1992, s. 573.

${ }^{21}$ Tamże, s. 170.

${ }^{22} \mathrm{DPL}$, nr 18. Oryginalne wydanie włoskie Direttorio su pietà popolare e liturgia. Principi e orientamenti używa terminu il rettore, co w polskim przekładzie przetłumaczono jako kustosz: „I Vescovi, come anche i rettori dei santuari, vigilino affinché le immagini sacre variamente riprodotte ad uso dei fedeli, per essere esposte nelle case o portate al collo o custodite presso di sé, non scadano mai nella banalità né inducano in errore". $\mathrm{Nr} 18$. 
sanktuariów oraz ich współpracownicy - księża, osoby konsekrowane i świeckie - są prawdziwymi filarami duszpasterskiego oddziaływania sanktuariów”23, jak również ,z [wydziałem diecezjalnym], odpowiedzialnym za organizację i koordynację duszpasterstwa pielgrzymek] powinni współpracować kustosze sanktuariów oraz zakony działające przy sanktuariach lub zajmujące się pielgrzymkami"24.

Należy teraz postawić pytanie: kim jest rektor (kustosz) sanktuarium? Analogicznie do postaci rektora kościoła ${ }^{25}$, trzeba powiedzieć, że rektorem sanktuarium jest kapłan, który kieruje ośrodkiem pielgrzymkowym zarówno w kwestiach duszpasterskich, jak i administracji majątkiem, zgodnie z prawem powszechnym i partykularnym ${ }^{26}$.

„Przez rektorów kościołów rozumie się (...) kapłanów, którym powierzono troskę o jakiś kościół, który nie jest ani parafialny, ani kapitulny, ani złączony z domem wspólnoty zakonnej lub stowarzyszenia życia wspólnego, którzy sprawują w nim święte czynności"27. Można skonstatować, że nazywając przełożonego sanktuarium „rektorem”, prawodawca chciał zrównać władzę rektora sanktuarium z funkcją rektorów kościołów ${ }^{28}$. X. Brossa zauważa, że w kan. $1232 \S 2$ prawodawca mógłby użyć innych pojęć (np. przełożony, kapelan, proboszcz itd.), które wskazywałyby na zrównywanie urzędu przełożonego sanktuarium z wymienionymi figurami prawnymi, ale Kodeks stosuje ter-

${ }^{23}$ Komisja Konferencu Episkopatu WŁoch ds. Duszpasterstwa cZasu wolnego, tuRYSTYKI I SPORTU, Pielgrzymowanie, nr 31.

${ }^{24}$ Tamże, nr 26; zob. np. Statut Sanktuarium Matki Bożej Trzykroć Przedziwnej i Zwycięskiej Królowej z Szensztatu na Górze Chetmskiej w Koszalinie (1 czerwca 2002), §6, 7, 19, Koszalińsko-Kołobrzeskie Wiadomości Diecezjalne 30(2002), nr 4-6, s. 42-49; Arcybiskup Metropolita SzcZecińsko-Kamieński, Dekret potwierdzający istnienie Sanktuarium Maryjnego w Brzesku (8 grudnia 1992), Prezbiterium 20(1992), nr 5, s. 328-329.

${ }^{25}$ Kan. 556-563.

${ }^{26}$ Por. X. Brossa, Régimen jurídico de los santuarios en el CIC, Roma 1996, s. 220.

${ }^{27}$ Kan. 556.

${ }^{28}$ Kan. 1232 § 2 . W KPK z 1983 r. figura rektora jest przewidziana tylko w kościołach rektorskich (kan. 556), w seminariach duchownych (kan. 239 §1), w sanktuariach (kan. 1232 §) i w uniwersytetach (kan. 443 §3, nr 3). 
min rektor sanktuarium ${ }^{29}$. Zatem kiedy sanktuarium nie jest kościołem parafialnym, kapitulnym, nie jest złączone domem wspólnoty zakonnej lub stowarzyszenia życia apostolskiego, zasadniczo do rektora będą miały zastosowanie kanony odnoszące się do rektorów kościołów ${ }^{30}$.

Wolą prawodawcy kodeksowego jest, aby każde sanktuarium było kierowane przez rektora (kustosza). Kan. 1232 § 2 wyraźnie poleca, że w statutach, które wprawdzie nie są obowiązkowe ${ }^{31}$, należy określić „zwłaszcza władzę rektora”. Choć poprzez użycie słowa „zwłaszcza” (praesertim = zwłaszcza, szczególnie) prawodawca chce powiedzieć, że nie zamierza dawać wyczerpującego katalogu materii prawnych, które winny być uregulowane w statucie, to mówiąc o władzy rektora, suponuje obowiązkowość tego urzędu w sanktuariach.

$\mathrm{Na}$ konieczność istnienia urzędu kustosza sanktuarium wskazują redaktorzy Direttorio su pietà popolare e liturgia w następującym fragmencie: ,adresatami dokumentu są także ich [biskupów] najbliżsi współpracownicy, czyli wikariusze biskupi, prezbiterzy i diakoni, a przede wszystkim rektorzy sanktuariów"32.

Także prawo partykularne eksponuje zasadniczą rolę urzędu kustosza. Prawodawcy przypominają, że ,na czele sanktuarium stoi miejscowy duszpasterz, któremu przysługuje tytuł «kustosza». To przede wszystkim od jego charyzmatu - inwencji i gorliwości - zależy żywotność sanktuarium”33 oraz że ,kustosz winien odznaczać się szczególnym umiłowaniem duszpasterstwa sanktuaryjnego"34.

${ }^{29}$ Régimen jurídico, s. 220.

${ }^{30}$ Kan. 556-563; por. X. BrossA, Régimen jurídico, s. 220-221.

${ }^{31} \mathrm{Nie}$ ma obowiązku posiadania przez sanktuarium statutów, jak na to wskazują prace nad rewizją Kodeksu. Por. Communicationes 12(1980), s. 343; por. J. MARTín DE AgAr, Comentare los cán. 1230-1234, w: Comentario exegético al Código de Derecho Canónico, pod red. A. Marzoa, J. Miras, R. Rodríguez-Ocaña, t. 3, cz. II, wyd. 3, Pamplona 2002, s. 1853.

${ }^{32} \mathrm{Nr} 5$.

${ }^{33}$ Pierwszy Synod Diecezji Kaliskiej 2007-2009. Prawo diecezjalne Kościoła Kaliskiego, Kalisz 2009, st. 655, s. 126.

${ }^{34}$ LXIX Synod Archidiecezji Poznańskiej (2004-2008), Poznań 2008, t. 2, st. 685, s. 148. „Kustosz sanktuarium jest odpowiedzialny za zorganizowanie opieki duszpasterskiej nad pielgrzymami”. Aby byli jedno. Drugi Synod Diecezji Sandomierskiej. 
Zależnie od okoliczności rektor sanktuarium może być jednocześnie przełożonym domu zakonnego, proboszczem, przewodniczącym kapituły itd. ${ }^{35}$. Tak więc niektórzy rektorzy oprócz obowiązków wynikających z ich pozycji prawnej (rektor kościoła, przełożony domu zakonnego, proboszcz, przewodniczącym kapituły) mają jeszcze obowiązki wynikające z kan. 1234 i z ewentualnego statutu czy innych przepisów prawa, odnoszących się ściśle do sanktuariów ${ }^{36}$.

Kwestie mianowania i utraty urzędu przez rektora winny być regulowane prawem powszechnym oraz precyzyjnie określone w ewentualnych statutach sanktuarium ${ }^{37}$. Wiele w tych sprawach będzie zależało od konkretnej sytuacji prawnej, w jakiej znajduje się określone sank-

Dekrety i Instrukcje, Sandomierz 1999, st. 464, s. 288 „Duszpasterską i religijną rolę Sanktuarium, a także zakres kompetencji jego kustosza reguluje Statut Regionalnego Sanktuarium Męki Pańskiej”. BISKUP KIELECKI, Dekret w sprawie sanktuarium w Imbramowicach (30 października 2003), Kielecki Przegląd Diecezjalny 80(2004), nr 1, s. 40 .

${ }^{35}$ Por. Biskup Legnicki, Dekret ustanawiajacy sanktuarium Matki Bożej Wojcieszowskiej w kościele parafialnym pw. Wniebowzięcia Najświętszej Maryi Panny $w$ Wojcieszowie $w$ dekanacie Świerzawa (15 września 2008), Legnickie Wiadomości Diecezjalne 13(2004), nr 4, s. 45; por. BISKUP OPOLSKI, Dekret ustanawiajacy sanktuarium świętego Józefa przy kościele Braci Mniejszych w Prudniku (8 marca 1998), Wiadomości Urzędowe Diecezji Opolskiej 51(1996), nr 6, §4, s. 284; „Jeżeli sanktuarium przynależy do parafii, wówczas kustoszem sanktuarium jest proboszcz tejże parafii. W przypadku kościoła rektorskiego kustoszem jest jego rektor. Jeżeli sanktuarium znajduje się na terytorium domu zakonnego, wówczas kustoszem sanktuarium jest przełożony lub przełożona domu". LXIX Synod Archidiecezji Poznańskiej, t. 2, st. $683 \S 3$, s. 148.

${ }^{36}$ Por. C. Rosell, Santuarios y basílicas en el derecho canónico vigente, Efemérides Mexicana 6(1988), nr 17, s. 42. Kiedy rektor z powodu istnienia różnych instytucji w samym sanktuarium, otrzymuje inne urzędy albo upoważnienia prawne (proboszcz, superior domu zakonnego, przewodniczący kapituły), w statutach sanktuarium trzeba precyzyjnie rozgraniczyć kompetencje rektora w stosunku do samego sanktuarium i do innych osób prawnych, i określić więzi, poprzez które podlega w różnych aspektach swojego urzędu biskupowi diecezjalnemu, proboszczowi, przełożonemu zakonnemu itd. X. Brossa, Régimen jurídico, s. 224.

${ }^{37}$ P. PALAzZin stwierdza, że kwestia ta może być z reguły ustalana w statucie sanktuarium, jeśli nie postanowiono inaczej, obowiązuje przepis kan. 571. Il santuario nel diritto canónico, La Madonna 32 (1984), nr 1-2, s. 61; por. X. BRossa, Régimen jurídico, s. 222. 
tuarium: czy jest ono diecezjalne, narodowe czy międzynarodowe, czy troska duszpasterska o dany ośrodek pielgrzymkowy jest powierzona instytutowi zakonnemu, czy innej osobie prawnej ${ }^{38}$.

$Z$ reguły rektor jest mianowany swobodnie przez biskupa diecezjalnego: „rektora kościoła mianuje swobodnie biskup diecezjalny, z zachowaniem prawa wyboru lub prezentacji, jeśli komuś zgodnie z prawem przysługuje"39. Aczkolwiek w wypadku sanktuarium narodowego albo międzynarodowego, Konferencja Biskupia albo Stolica Apostolska mogłyby w większym albo mniejszej wymiarze mieć udział w jego nominacji ${ }^{40}$.

Zwykle, kiedy troska duszpasterska o sanktuarium jest powierzona instytutowi zakonnemu, przypada w udziale przełożonemu prawo przedstawienia kandydata: „również wtedy, gdy kościół należy do jakiegoś instytutu kleryckiego na prawie papieskim, biskupowi diecezjalnemu przysługuje prawo ustanowienia rektora przedstawionego przez przełożonego" ${ }^{41}$.

Utrata urzędu rektora następuje według postanowienia kan. 184 §1: „urząd kościelny traci się po upływie wyznaczonego czasu, po osiągnięciu określonego prawem wieku, na skutek rezygnacji, przeniesienia, usunięcia a także pozbawienia" ${ }^{42}$. Trzeba dodać, że zagadnienie to winno być także uregulowane w ewentualnych statutach sanktuarium, czy w prawie partykularnym.

${ }^{38} \mathrm{~W}$ niektórych sanktuariach rektorem samo przez się (,urodzonym”) jest superior domu zakonnego albo stowarzyszenia życia apostolskiego, z którym złączone jest sanktuarium, przewodniczący kapituły kolegiackiej do której należy sanktuarium, albo sam proboszcz w przypadku kościoła parafialnego - sanktuarium; w innych rektorem będzie kapłan mianowany przez biskupa diecezjalnego z obowiązkami, które określają kan. 556-563. C. Rosell, Santuarios y basílicas, s. 185.

${ }^{39}$ Kan. $557 \S 1$.

${ }^{40}$ Por. X. Brossa, Régimen jurídico, s. 222; por. kan. 1232 §1. A. Nicora utrzymuje, że rektor sanktuarium narodowego albo międzynarodowego powinien być mianowany przez Konferencję Biskupią lub Stolicę Apostolską. Gli statuti dei santuari e relativi problemi giuridico-amministrativi, La Madonna 36(1988), nr 2, s. 85.

${ }^{41}$ Kan. $557 \S 2$.

${ }^{42}$ Zob. R. Sobański, Komentarz do kan. 184, w: Komentarz do Kodeksu Prawa Kanonicznego. T. 1. Ks. 1. Normy ogólne, pod red. J. Krukowskiego, Poznań 2003, s. 274-275. 
W zasadzie z powodu słusznej przyczyny i według własnego, roztropnego uznania, ordynariusz miejsca może usunąć rektora z jego urzędu: ,zgodnie z własnym osądem, ordynariusz miejsca może dla słusznej przyczyny usunąć rektora kościoła, chociażby był przez innych wybrany lub prezentowany, z zachowaniem przepisu kan. 682 $\S 2 " 43$.

W przypadku rektora zakonnego usunięcie może być dokonane przez biskupa diecezjalnego, po uprzednim zawiadomieniu przełożonego zakonnego, albo przez przełożonego zakonnego po powiadomieniu biskupa diecezjalnego ${ }^{44}$. Trzeba dodać, że procedura usuwania proboszczów ustalona w kan. 1740-1747 KPK nie jest wiążąca w stosunku do proboszczów (w tym przypadku rektorów sanktuarium), którzy są członkami instytutu zakonnego lub stowarzyszenia życia apostolskiego. Mogą oni być usunięci stosowanie do uznania (ad nutum) biskupa diecezjalnego, bądź własnego przełożonego. W tym wypadku nie jest wymagane zaistnienie przyczyn wymienionych w kan. 1740-1741, ani zachowanie procedury określonej w kan. 1742. Wynika to $\mathrm{z}$ faktu, że zakonnik na mocy ślubu jest zobowiązany do posłuszeństwa ${ }^{45}$.

Przez analogię z postępowaniem w sprawie usunięcia proboszcza ${ }^{46}$, które jest określone w kan. 1740-1747 KPK, można wydedukować niektóre przyczyny usunięcie rektora sanktuarium. By przystąpić do jego usunięcia, posługiwanie rektora musi być „szkodliwe lub przynajmniej nieskuteczne" ${ }^{47}$. Jako przykład mogą posłużyć przyczyny wymienione w kan. 1741. Przyczyny, dla których proboszcz może być

${ }^{43}$ Kan. 563; por. X. Brossa, Régimen jurídico, s. 224.

${ }^{44}$ Por. kan. $682 \S 2$.

${ }^{45}$ J. Krukowski, Prawo administracyjne w Kościele, Warszawa 2011, s. 414; zob. G. LeszCZyŃski, Kościelna procedura administracyjna $w$ Kodeksie Prawa Kanonicznego Jana Pawła II, Warszawa 2008, s. 164-165.

${ }^{46}$ „Proboszcz traci swój urząd przez usunięcie lub przeniesienie, dokonane zgodnie z przepisami prawa przez biskupa diecezjalnego; przez zrzeczenie się dla słusznej przyczyny, dokonane przez samego proboszcza i, do ważności, przyjęte przez biskupa diecezjalnego, jak również po upływie czasu, jeśli proboszcz zgodnie z przepisami prawa partykularnego, o którym w kan. 522, był ustanowiony na oznaczony czas". Kan. $538 \S 1$. Kan. $193 \S 1$.

${ }^{47}$ Kan. 1740; por. AS, nr 213. 
usunięty z parafii zgodnie z przepisami prawa, są zwłaszcza następujące: 1. sposób postępowania, który przynosi kościelnej wspólnocie poważną szkodę lub zamieszanie; 2. nieudolność albo trwała choroba umysłowa lub fizyczna, która czyni proboszcza nieużytecznym w wypełnianiu jego zadań; 3. utrata dobrego imienia u uczciwych i poważnych parafian lub niechęć w stosunku do proboszcza, które według przewidywania szybko nie ustaną; 4. poważne zaniedbanie lub naruszanie obowiązków parafialnych, które trwa mimo upomnienia; 5. złe zarządzanie dobrami doczesnymi, z wielką szkodą Kościoła, ilekroć na zaradzenie złu brak innego środka ${ }^{48}$.

Dyrektorium o pasterskiej postudze biskupów „Apostolorum Successores” przypomiona, że „usunięcie lub przeniesienie proboszcza mogą mieć miejsce tylko z bardzo ważnych powodów i zgodnie z procedurą ustaloną przez prawo"49.

Jeżeli na podstawie przeprowadzonego badania ustali się, że istnieje przyczyna, o której w kan. 1740, biskup omawia sprawę z dwoma proboszczami, wybranymi z zespołu ustanowionego na stałe w tym celu przez Radę kapłańską; jeśli biskup dojdzie do wniosku, że należy przystąpić do usunięcia, podając - do ważności - przyczynę i argu-

${ }^{48}$ Kan. 1741. Należy jednak zauważyć, że wymieniony katalog przeszkód w wykonywaniu urzędu proboszcza (rektora) nie jest wyczerpujący, jak na to wskazuje przebieg dyskusji konsultorów nad kwestią regulowaną przez aktualny kan. 1741 oraz użyte w kan. 1741 słowa „są zwłaszcza następujące” (hae praesertim sunt). Należy sądzić, że prawodawca będzie uzupełniał katalog przyczyn administracyjnego usunięcia proboszcza (rektora), ilekroć zaistnieje inne zagrożenie potrzeb duchowych wiernych. Por. K. Orzeszyna, Przyczyny administracyjnego usunięcia proboszcza, Biuletyn Stowarzyszenia Kanonistów Polskich 13(2003), nr 16, s. 70, 78-79; J. KRUKowsKi, Komentarz do kan. 1741, w: Komentarz do Kodeksu Prawa Kanonicznego. T. V. Ks. VII. Procesy, pod red. J. Krukowskiego, Poznań 2007, s. 438; J. KRUKowski, Prawo administracyjne $w$ Kościele, s. 411-413.

${ }^{49} \mathrm{Nr} 213$. „Dobro dusz niech będzie najwyższym prawem strzeżonym przez biskupa w dobieraniu, usuwaniu lub przenoszeniu proboszczów, a także w przyjmowaniu złożonego przez nich zrzeczenia. Z tym rzeczywiście łączy się zachowanie słuszności prawa naturalnego lub kanonicznego". SACRA CONGREGATIO PRO EPISCOPIS, Directorium Ecclesiae imago de pastorali ministerio Episcoporum (22 februarii 1973), nr 206 e, w: Enchiridion Vaticanum, t. 4, Bologna 1997 nr 1945-2328, tekst polski: E. SzTAFrowski, Posoborowe Prawodawstwo Kościelne, t. 6, z. 1, nr 10370-11035, (odtąd: EI). 
menty, radzi proboszczowi (rektorowi) po ojcowsku, by zrezygnował w ciągu piętnastu dni ${ }^{50}$. Jeśli po drugim wezwaniu rektor nie zrzekałby się, biskup winien wydać dekret usunięcia ${ }^{51}$. Przeciw dekretowi usunięcia rektora jest możliwy rekurs administracyjny do Kongregacji Duchowieństwa $^{52}$. Od decyzji wspomnianej Kongregacji usunięty proboszcz (rektor) może odwołać się do Sygnatury Apostolskiej z tytułu nielegalności aktu ${ }^{53}$.

\section{Kwalifikacje kustosza i jego formacja}

Według kan. 149 § 1 urząd kościelny można komuś powierzyć, kto pozostaje we wspólnocie Kościoła i jest zdatny, czyli posiadać przymioty wymagane do tego urzędu prawem powszechnym, partykularnym lub fundacyjnym. Jest zrozumiałe, że przytoczona norma odnosi się także do urzędu kustosza sanktuarium.

Urząd kościelny można powierzyć jedynie osobie zdatnej, czyli spełniającej wymogi zarówno ogólne, czyli bezwzględne (stawiane kandydatom do jakiegokolwiek urzędu kościelnego), jak też szczegółowe, czyli względne (wynikające z natury urzędu, który ma być nadany). Przymioty wymagane do konkretnego urzędu określa prawo powszechne, partykularne lub fundacyjne - czy to wprost $^{54}$, czy to

${ }^{50}$ Kan. $1742 \S 1$.

${ }^{51}$ Kan. 1744 §2; por. J. Krukowski, Prawo administracyjne w Kościele, s. 414-417.

52 Por. kan. 1747 §3; Joannes Paulus P.P. II, Constitutio Apostolica Pastor Bonus, (28 iulii 1988), art. 93, Acta Apostolicae Sedis 80(1988), s. 841-912, (odtąd: PB). por. X. Brossa, Régimen jurídico, s. 225; por. J. Krukowski, Komentarz do kan. 1747, w: Komentarz do Kodeksu Prawa Kanonicznego. T. V. Ks. VII. Procesy, pod red. J. Krukowskiego, Poznań 2007, s. 445.

${ }^{53}$ Benedictus PP. XVI, Litterae Apostolicae motu proprio datae Antiqua ordinatione, „Quibus Supremi Tribunalis Signaturae Apostolicae lex propria promulgatur," (21 iunii 2008), art. 34 §1-2, Acta Apostolicae Sedis 100(2008), s. 513-538; por. B. NowaKowsKI, Kompetentne i sprawnie działajace trybunały kościelne. Rzeczywistość czy pobożne życzenie? Możliwości, perspektywy oraz konieczność zmian po słowach Benedykta XVI do Sygnatury Apostolskiej w 2011 r., Prawo Kanoniczne 54(2011), nr 3-4, s. 330.

${ }^{54}$ Np. kan. 478; $494 \S 1$. 
pośrednio $^{55}$. Sąd o zdatności należy do władzy nadającej urząd, a jeśli jakiś podmiot ma prawo przedstawiania kandydata, winien przedtem upewnić się o jego zdatności. Wymagane przymioty są określane w prawie w sposób albo wiążący ${ }^{56}$, albo też dyrektywny ${ }^{57}$. Ujmuje się je od strony negatywnej ${ }^{58}$ lub pozytywnej ${ }^{59}$.

Tak więc rektor sanktuarium winien być zdatny, czyli posiadać przymioty wymagane do tego urzędu prawem powszechnym, partykularnym lub fundacyjnym. Kodeks Prawa Kanonicznego z 1983 r. nie wypowiada się na temat zdatności kandydata na kustosza. Jednakże nazywając przełożonego sanktuarium ,rektorem"60, prawodawca chciał zrównać władzę rektora sanktuarium z funkcją rektorów kościołów. Rektorem kościoła jest kapłan, któremu powierzono troskę o jakiś kościół, który nie jest ani parafialny, ani kapitulny, ani złączony z domem wspólnoty zakonnej lub stowarzyszenia życia wspólnego, którzy sprawują w nim święte czynności ${ }^{61}$.

Niekiedy kustosz może jednocześnie pełnić urząd przełożonego domu zakonnego, proboszcza, prepozyta kapituły itd. W takich przypadkach każdy rektor oprócz obowiązków wynikających z jego pozycji prawnej (rektor kościoła, przełożony domu zakonnego, proboszcz, przewodniczącym kapituły) ma jeszcze obowiązki wynikające z kan. 1234 i z ewentualnego statutu czy innych przepisów prawa, odnoszących się ściśle do sanktuariów ${ }^{62}$. Tak zatem urząd kustosza jako taki, wymaga od kandydata stosownych przymiotów.

${ }^{55}$ Np. jako zdatność do biskupstwa - kan. 378 §1, czy do kapłaństwa - kan. 1026.

${ }^{56}$ Por. np. kan. 378 §1 n. 3 i 4.

${ }^{57}$ Por. np. kan. $378 \S 1$ n. 5: „...lub prawdziwej biegłości”.

${ }^{58}$ Np. kan. $317 \S 4 ; 483 \S 2$ - , ponad wszelkim podejrzeniem”.

${ }^{59}$ Por. R. Sobański, Komentarz do kan. 149, w: Komentarz do Kodeksu Prawa Kanonicznego. T. 1. Ks. 1. Normy ogólne, pod red. J. Krukowskiego, Poznań 2003, s. 239.

${ }^{60}$ Kan. $1232 \S 2$.

${ }^{61}$ Por. kan. 556.

${ }^{62}$ Por. C. Rosell, Santuarios y basílicas, s. 42. Kiedy rektor z powodu istnienia różnych instytucji w samym sanktuarium, otrzymuje inne urzędy albo upoważnienia prawne (proboszcz, superior domu zakonnego, przewodniczący kapituły), w statutach sanktuarium trzeba precyzyjnie rozgraniczyć kompetencje rektora w stosunku do sa- 
Gdy chodzi o kwalifikacje kandydata na kustosza, to wydaje się, że winny być one wyższe od przymiotów kandydata na proboszcza parafii, gdyż sanktuarium z powodu licznego napływu różnych wiernych i wzorcowo sprawowanego duszpasterstwa wymaga od rektora wysokiego poziomu duchowego, intelektualnego i zdolności organizacyjnych. Mianowanie kapłana o takich kwalifikacjach jest jednocześnie prawem pielgrzymów do obfitszego otrzymania dóbr duchowych i doczesnych w sanktuarium.

Według obowiązującego KPK, aby określony prezbiter mógł ważnie zostać proboszczem, winien odznaczać się zdrową nauką i dobrymi obyczajami, gorliwością pasterską oraz innymi cnotami, jak również przymiotami, wymaganymi, czy to prawem powszechnym czy partykularnym, do kierowania parafią, o którą chodzi ${ }^{63}$. Redaktorzy instrukcji Kapłan, pasterz i przewodnik wspólnoty parafialnej przypominają, że „w kan. 521 §2 są wymienione, choć nie wyczerpująco, główne przymioty osobowe, składające się na kanoniczną zdatność kandydata na urząd proboszcza: zdrowa nauka i dobre obyczaje, gorliwość pasterska oraz inne cnoty, jak również przymioty wymagane czy to prawem powszechnym (to znaczy winien spełniać wymagania określone dla

mego sanktuarium i do innych osób prawnych, i określić więzi, przez które podlega w różnych aspektach swojego urzędu biskupowi diecezjalnemu, proboszczowi, przełożonemu zakonnemu itd. X. Brossa, Régimen jurídico, s. 224.

${ }^{63}$ Kan. 521 §2; por. A. SÁncheZ - GiL, Comentare el can. 521, w: Comentario exegético al Código de Derecho Canónico, pod red. A. Marzoa, J. Miras, R. RodríguezOcaña, t. 2, cz. II, wyd. 3, Pamplona 2002, s. 1240. „Przy wyrabianiu sobie sądu o zdolności kapłana do zarządzania jakąś parafią biskup winien wziąć pod uwagę nie tylko jego wiedzę, lecz również pobożność, gorliwość apostolską oraz inne uzdolnienia i cechy, które są wymagane do należytego wykonywania zadań duszpasterskich". Concilium Oecumenicum Vaticanum II, Decretum de pastorali Episcoporum munere in Ecclesia Christus Dominus, nr 31, Acta Apostolicae Sedis 58(1966), s. 673-701, tekst polski: SoBÓR WaTYKAŃSKI II, Dekret o pasterskich zadaniach biskupów w Kościele Christus Dominus, w: Sobór Watykański II. Konstytucje, dekrety, deklaracje. Tekst polski. Nowe thumaczenie, Poznań 2002, s. 236-258. Należy dodać, że przytoczony passus jest jednym ze źródeł aktualnego kan. 521 \$2. Pontificia Commissio Codici Iuris Canonici Authentice Interpretando, Codex Iuris Canonici Auctoritate Ioannis Pauli PP. II promulgatus. Fontium annotatione et indice analitico-alphabetico auctus, Libreria Editrice Vaticana 1989, przypis do kan. 521 §2. 
duchownych w ogóle, por. kan. 273-279), czy prawem partykularnym (to znaczy winien odznaczać się przymiotami mającymi szczególne znaczenie w jego Kościele partykularnym)" ${ }^{\text {64 }}$.

Także per analogiam kustosz, choć w większym stopniu winien odznaczać się zdrową nauką i dobrymi obyczajami, gorliwością pasterską oraz innymi cnotami, jak również przymiotami, wymaganymi czy to prawem powszechnym, czy partykularnym, do kierowania określonym sanktuarium. Niewątpliwie prawo partykularne, czy statut określonego sanktuarium mogłyby żądać jeszcze innych kwalifikacji od kandydatów na rektora sanktuarium, niż wymagane są na urząd proboszcza ${ }^{65}$.

Na podstawie dyspozycji prawa powszechnego, od proboszcza (kustosza) wymaga się - w sposób szczególny, ze względu na ważność jego urzędu - wypełniania obowiązków ustalonych dla wszystkich duchownych: okazywania szacunku i posłuszeństwa Papieżowi oraz własnemu ordynariuszowi ${ }^{66}$; wspieranie jedności, braterstwa i modlitwy z innymi wiernymi (duchowni i świeccy) ${ }^{67}$; dążenie do świętości poprzez wykonanie swojej posługi duszpasterskiej, posilanie swojego życia duchowego Eucharystią i Pismem Świętym, liturgią godzin, odprawianie rekolekcji, modlitwy myślnej, częste spowiadanie się, oddawanie szczególnej cześć Bogurodzicy Dziewicy i praktykowanie innych powszechnych i partykularnych środków uświęcenia ${ }^{68}$; troskliwe zachowanie celibatu ${ }^{69}$; pogłębianie znajomości nauk świętych i metod duszpasterskich ${ }^{70}$.

Odnośnie do omawianych przymiotów rektora sanktuarium, w pewnym sensie mogą pomóc zalecenia Dyrektorium Apostolorum

\footnotetext{
${ }^{64}$ Congregazione Per Il Clero, Istruzione $I l$ presbitero, pastore e guida della comunità parrocchiale (4 agosto 2002), nr 20, przypis 82, Città del Vaticana 1999, tekst polski: Kongregacja DS. DuchowieńsTwA, Instrukcja Kapłan, pasterz i przewodnik wspólnoty parafialnej (4 sierpnia 2002 r.), Poznań 2002.

${ }^{65}$ Por. A. SÁnchez - GiL, Comentare el can. 521, s. 1240-1241.

${ }^{66}$ Por. kan. 273.

${ }^{67}$ Por. kan. 275.

${ }^{68}$ Por. kan. 276.

${ }^{69}$ Por. kan. 277.

${ }^{70}$ Por. kan. 279.
} 
Successores dotyczące wyboru kandydata na proboszcza: „zważywszy na znaczenie roli proboszcza dla troski o dusze, biskup dokona jego wyboru ze szczególną sumiennością. Poprzez odpowiedni sondaż na temat szczególnych potrzeb parafii, z pomocą dziekana, z którym koniecznie się skonsultuje, upewni się najpierw, że znalazł właściwą osobę, która nie tylko wyróżnia się zdrową nauką i dobrymi obyczajami, lecz również gorliwością apostolską oraz innymi cnotami wymaganymi do należytego wykonywania tej posługi w parafii - komunikatywnością oraz uzdolnieniami organizacyjnymi i w dziedzinie zarządzania. Weźmie także roztropnie pod uwagę środowisko, możliwości i problemy, jakim należy sprostać $\mathrm{w}$ parafii, starając się posłać tam takiego kapłana, który będzie mógł dobrze włączyć się w specyficzne zadania parafii" ${ }^{\prime \prime}$.

Na temat przymiotów proboszcza wypowiada się też dyrektorium Ecclesiae imago. Autorzy stwierdzają, że „mając na uwadze znaczenie stanowiska proboszczowskiego w Kościele, jak również pouczony doświadczeniem, że dobrzy proboszczowie przyczyniają się w parafiach w dużym stopniu do wiecznego zbawienia wiernych, mianowicie tacy, którzy kierując się duchem Bożym całkowicie poświęcają się duszpasterstwu - biskup dobiera proboszczów ze szczególną troskliwością. Dla wyrobienia sobie odpowiedniego sądu (zdania) o ich zdatności, bierze pod uwagą nie tylko ich wiedzę, lecz także pobożność, gorliwość apostolską oraz inne cnoty i uzdolnienia, jakich się domaga sprawne prowadzenie duszpasterstwa. (...) Dobro dusz niech będzie najwyższym prawem strzeżonym przez Biskupa w dobieraniu, usuwaniu lub przenoszeniu proboszczów, a także w przyjmowaniu złożonego przez nich zrzeczenia. $Z$ tym rzeczywiście łączy się zachowanie słuszności prawa naturalnego i kanonicznego" 72 .

Prawodawcy partykularni niejednokrotnie doprecyzowują szczególne kwalifikacje, jakie powinien posiadać kustosz sanktuarium. Celowe będzie więc przykładowe przywołanie w tym miejscu niektórych przepisów prawnych: np. ,na czele sanktuarium stoi miejscowy dusz-

\footnotetext{
$71 \mathrm{Nr} 213$.

${ }^{72}$ EI, nr 206 e.
} 
pasterz, któremu przysługuje tytuł «kustosza». To przede wszystkim od jego charyzmatu - inwencji i gorliwości - zależy żywotność sanktuarium. Kustosz powinien zaprosić do współpracy z sanktuarium grono duchownych i świeckich, którzy będą go wspierać w organizowaniu duszpasterstwa sanktuaryjnego nie tylko w dniach odpustu, lecz także w ciągu roku"73; ,kustosz winien odznaczać się szczególnym umiłowaniem duszpasterstwa sanktuaryjnego i odpowiednimi uzdolnieniami duszpasterskimi" 74 ; ,kustosz sanktuarium jest odpowiedzialny za zorganizowanie opieki duszpasterskiej nad pielgrzymami, zarówno w wymiarze duchowym, jak i socjalnym"75. Ważny w tym kontekście jest passus zaczerpnięty z dokumentu Pielgrzymowanie u progu trzeciego tysiaclecia Konferencji Episkopatu Włoch, gdzie czytamy: „W posługę w sanktuarium, do różnych zadań, należy włączyć różne osoby, cechujące się ludzką otwartością i życzliwością wobec przybywających, o dużej przenikliwości duchowej i teologalnej inteligencji, które potrafią wprowadzić nawiedzających do sanktuarium jako wydarzenia łaski, miejsca doświadczenia religijnego, odnalezionej radości. Osoby odpowiedzialne za przyjęcie duszpasterskie powinny uwzględniać specyficzną tożsamość każdej pielgrzymki oraz odrębne cechy osobiste wiernych, tak aby móc stworzyć korzystne warunki do rozmowy z Bogiem, wysłuchania Jego słowa, posłuszeństwa Duchowi"76.

73 SynOd KaLISKI, st. 655, s. 126. A więc musi mieć zdolność do współpracy z innymi odpowiedzialnymi za duszpasterstwo w sanktuarium.

${ }^{74}$ LXIX Synod Archidiecezji Poznańskiej, t. 2, st. 685, s. 148.

${ }^{75}$ Synod SAndomierski, st. 464, s. 288-289; por. III Synod DiecezJI Kieleckiej, Kielce 1992, Instrukcja o sanktuariach, § 1 a, s. 271.

${ }^{76} \mathrm{Nr} 31$. To przede wszystkim kustosz winien odznaczać się ludzką otwartością i życzliwością wobec pielgrzymów, posiadać dużą przenikliwość duchową i teologalną inteligencję oraz wrażliwość na każdego przybywającego do sanktuarium. Rektor winien ,mieć także odpowiednie przygotowanie psychologiczne, aby mógł przyjąć i zrozumieć indywidualność każdego pielgrzyma. Bardzo pożyteczna będzie również znajomość historii i sztuki”. Pontificio Consiglio DELla PASTORALE PER I MIGRANTI E GLI ITINERANTI, Il pellegrinaggio nel grande giubileo del 2000 (25 aprile 1998), nr 35, Enchiridion Vaticanum, t. 17, tekst polski: Papieska Rada ds. DuszPasterstwa MigranTów I Podróżnych, Pielgrzymka w Wielkim Jubileuszu Roku 2000 (25 kwietnia 1998), Salvatoris Mater 1(1999) nr 3, s. 323-347. 
Ponadto kustosz winien odznaczać się ewangeliczną gościnnością i postawą serdeczności wobec przybywających pielgrzymów ${ }^{77}$, wrażliwością na drugiego człowieka ${ }^{78}$, dawać przykład postawy kapłańskiej $^{79}$.

Kan. $521 \S 3$ postanawia, że aby ktoś mógł otrzymać urząd proboszcza, należy - w sposób określony przez biskupa diecezjalnego, także przy pomocy egzaminu - przekonać się o jego zdatności. Także odnośnie rektora sanktuarium kompetentna władza kościelna winna przekonać się, że kandydat posiada określone przymioty umożliwiające mu owocne kierowanie danym sanktuarium. Wybór kustosza winien więc być dokonany ze szczególną sumiennością, po konsultacji z dziekanem, czy innymi prezbiterami. Należy roztropnie brać pod uwagę środowisko, możliwości i problemy, jakim należy sprostać w danym sanktuarium $^{80}$.

Jest oczywiste, że doniosłość wykonywania duszpasterstwa sanktuaryjnego wymaga od rektora nie tylko posiadania stosownych przymiotów, ale i stałej formacji ${ }^{81}$. Kodeks Prawa Kanonicznego z 1983 r. wymaga takiej formacji od duchownych ${ }^{82}$, osób konsekrowanych ${ }^{83}$ i laików ${ }^{84}$. Papież Jan Paweł II przypominał, że „stała formacja kapłanów, zarówno diecezjalnych, jak i zakonnych, jest naturalną i absolutnie niezbędną kontynuacją procesu kształtowania osobowości kapłańskiej, rozpoczętego i prowadzonego $\mathrm{w}$ seminarium lub w domu zakonnym

${ }^{77}$ Por. IV Synod Diecezji Tarnowskiej, Ad imaginem ecclesiae universalis, Tarnów 1990, st. 309, s. 146. „Kustosz zapewnia w sanktuarium (...) przyjazną, rodzinną atmosferę pobytu”. SynOd KaLisKi, st. 655, s. 126.

${ }^{78}$ Por. Komisja Konferencu Episkopatu WŁoch ds. Duszpasterstwa cZasu wolnego, TURYSTYKI I SPORTU, Pielgrzymowanie, nr 31.

${ }^{79}$ Por. Statuty I Synodu Diecezı Pelplińskiej, Pelplin 2001, Aneks nr 27, Instrukcja duszpasterska dla sanktuarium, nr 10, s. 195.

${ }^{80}$ Por. AS, nr 213.

${ }^{81}$ Por. M. Ostrowski, Jesteśmy pielgrzymami, s. 257-259; por. tenże, Sanktuarium w teologiczno-duszpasterskiej, s. 61.

${ }^{82}$ Por. kan. 279.

${ }^{83}$ Por. kan. 661.

${ }^{84}$ Por. kan. 232. 
W ramach formacji przygotowującej do przyjęcia święceń" ${ }^{85}$. Kustosz jest zobowiązany poddać się ustawicznemu kształceniu według ustaleń prawa partykularnego: „kustosz winien (...) stale pogłębiać wiedzę teologiczną" "86, pracownicy sanktuarium winni odbywać specyficzną formację, odpowiednią do podejmowanej przez nich służby ${ }^{87}$; , Referat Sanktuariów organizuje przynajmniej raz w roku ogólnodiecezjalne spotkanie kustoszów dla omówienia aktualnych zadań duszpasterstwa sanktuaryjnego"88; „kustosze sanktuariów winni regularnie spotykać się ze sobą w celu pogłębiania swojej wiedzy teologicznej, doskonalenia metod pracy i wymiany doświadczeń" 89 .

\section{Zadania rektora sanktuarium}

Każde sanktuarium pełni funkcję i ma cel typowo duszpasterski, które prawo winno uwzględniać i stosownie regulować ${ }^{90}$. Prawodawca w kan. 1233 i 1234 pragnął wyraźnie zaakcentować wybitnie duszpasterskie zadania sanktuariów, chociaż wystarczyłoby rozpatrywanie ich jako miejsc kultu. W każdym bowiem miejscu świętym promuje się kult Boży, pobożność i pożytek duchowy wiernych, a środki służące temu są zasadniczo zawsze te same: liturgia, szczególnie celebracja

${ }^{85}$ IoAnnes Paulus PP. II, Adhortatio Apostolica Postsynodalis: Pastores dabo vobis (25 marti 1992), nr 71, Acta Apostolicae Sedis 84(1992), 657-804.

${ }^{86}$ LXIX SYNOD PozNAŃSki, t. 2, st. 685, s. 148.

${ }^{87}$ Por. Pontificio Consiglio della Pastorale Per I migranti E GLi itineranti, $\mathrm{Il}$ santuario. Memoria, presenza e profezia del Dio vivente, (8 maggio 1999), $\mathrm{nr}$ 10, 17, Notitiae 35(1999) 343-373, tekst polski: Papieska Rada ds. DuszPasterstwa MigranTÓw I Podróżnych, Sanktuarium. Pamięć, obecność i proroctwo Boga żywego (8 maja 1999), Salvatoris Mater 1(1999) nr 3, s. 301-322.

${ }^{88}$ SYNOD TARNOWSKI, st. 314 § 2, s. 147.

${ }^{89}$ LXIX Synod Poznański, t. 2, st. 689, s. 149.

${ }^{90}$ Papież Jan Paweł II wielokrotnie ukazywał sanktuaria jako miejsce szczególnie odpowiednie dla duchowej odnowy pielgrzymów: „wystarczy popatrzeć na rzesze pielgrzymów, ludzi dorosłych i młodych, zdążających do Sanktuariów Maryjnych i zapatrzonych w wizerunek Bogarodzicy, czasem Maryi i Józefa wraz z Dzieciątkiem: w oblicza, na których odbija się całe piękno miłości ofiarowanej człowiekowi przez Boga". Giovanni Paolo II, Lettera alle famiglie Gratissimam sane (2 febbraio 1994), nr 20, Acta Apostolicae Sedis 86(1994), 868 - 925; por. X. Brossa, Régimen jurídico, s. 293-294. 
Mszy św. i innych sakramentów oraz przepowiadanie Ewangelii ${ }^{91}$. Jednakże w miejscach pielgrzymkowych wymienione czynności święte winny być spełniane obficiej (abundantius media salutis), intensywniej w stosunku do innych miejsc kultu. Czynności te tyczą się posługi słowa Bożego i celebracji liturgicznych, szczególnie sprawowania sakramentów Eucharystii i pokuty, jak również kultywowania zatwierdzonych przez kompetentną władzę kościelną form pobożności ludowej (probatas pietatis popularis formas) ${ }^{92}$.

Podstawową powinnością rektora sanktuarium jest zapewnienie pielgrzymom obfitszych środków zbawienia ${ }^{93}$. Obowiązki kustosza w tej kwestii są jednocześnie prawem pątników ${ }^{94}$. To przede wszystkim rektor ma czynić starania, aby przybywającym do sanktuarium wiernym dostarczano obficiej niż w innych miejscach świętych zwyczajnych środków zbawienia, to znaczy słowa Bożego i sakramentów św. ${ }^{95}$

Dyrektorium Peregrinans in terra z 1969 r. poleca m.in. rektorom sanktuariów ,zabiegać, żeby więcej doceniano turystykę religijną (pielgrzymki), zabezpieczając jej religijny pierwiastek oraz sakralny charakter tradycyjnych dni świątecznych danej miejscowości”, a także ,podnosić szacunek dla sanktuariów znajdujących się w diecezji (...) z uwagi na ich wielki wkład, jaki one wnoszą w rozdawnictwo Sakramentów Pokuty i Eucharystii" 96 . Pośrednio o omawianych tu obowiąz-

${ }^{91}$ Por. kan. 1205; „w nowym Kodeksie Prawa Kanonicznego sanktuaria cieszą się wyjątkowym uznaniem prawnym co wskazuje na ich doniosłe znaczenie duszpasterskie na danym terenie (kan. 1230)". OPCM, nr 73; por. J. MARTín dE AgAR, Comentare los cán. 1230-1234, s. 1855-1856.

${ }^{92}$ Kan. 1234 § 1; por. X. BrossA, Régimen jurídico, s. 126-127.

${ }^{93}$ Kan. $1234 \S 1$ wskazuje w trybie rozkazującym na obowiązki i zadania wszystkich sanktuariów: ,w sanktuariach należy zapewnić wiernym obfitsze środki zbawienia”. Por. C. Rosell, Santuarios y basílicas, s. 188.

${ }^{94}$ Por. kan. 213.

${ }^{95}$ Por. C. Rosell, Santuarios y basílicas, s. 189.

${ }^{96}$ Sacra Congregatio pro Clericis, Directorium generale pro ministerio pastorali quoad turismum Peregrinans in terra (30 aprilis 1969), cz. II B, d, Acta Apostolicae Sedis 61(1969), s. 361-384, tekst polski: Posoborowe Prawodawstwo Kościelne t. II, z. 2, nn. 2769-2932. 
kach kustosza mówi dyrektorium Ecclesiae imago, gdzie prawodawca zobowiązuje biskupa, aby szczególnie czuwał nad przepowiadaniem słowa Bożego i udzielaniem sakramentów w sanktuariach ${ }^{97}$.

Redaktorzy dyrektorium o pasterskiej posłudze biskupów „Apostolorum Successores" przypominają odpowiedzialnym za ośrodki pątnicze, że ,w sanktuariach (...) gdzie otacza się wiernych troską duchową, powinno się ułatwiać im dostęp do spowiedzi, wyznaczając na nią odpowiedni czas (przede wszystkim przed Mszą świętą, ale także podczas niej), w ten sposób wychodząc naprzeciw ich potrzebom"98.

Z kolei papież Jan Paweł II liście apostolskim motu proprio Misericordia Dei zobowiązuje m.in rektorów sanktuariów, aby okresowo sprawdzali ,czy faktycznie wierni mają możliwie najbardziej ułatwiony dostęp do spowiedzi. W szczególności zaleca się, by spowiednicy byli obecni i widoczni w miejscach kultu w określonych godzinach, wyznaczonych według rozkładu dostosowanego do rzeczywistej sytuacji penitentów, a zwłaszcza gotowość do spowiadania przed Mszami świętymi, jak również, gotowość do wyjścia naprzeciw potrzebom wiernych także podczas celebracji Mszy świętych, jeśli są obecni inni kapłani"99.

Redaktorzy Direttorio su pietà popolare e liturgia zobowiązują kustoszów do gorliwego głoszenie słowa Bożego odnoszącego się zarówno do jego treści, form jak i środków ${ }^{100}$, a także do działalności ekumenicznej ${ }^{101}$.

Według Dyrektorium o pobożności ludowej i liturgii „odpowiedzialni za sanktuaria powinni uczynić wszystko, by sprawowana tam liturgia była przykładna w swym wykonaniu. «Do zadań, jakie mają pełnić sanktuaria, wymaganych również przez Prawo Kanoniczne, należy troska o stały rozwój życia liturgicznego. Nie chodzi tutaj o zwiększenie częstotliwości sprawowanych obrzędów, ale o ich coraz lepszą jakość. Troska ta ciąży przede wszystkim na rektorach sanktuariów. Dlatego

\footnotetext{
${ }^{97} \mathrm{EI}, \mathrm{nr} 90 \mathrm{~b}$.

${ }^{98} \mathrm{AS}, \mathrm{nr} 151$.

${ }^{99}$ IoAnNes Paulus P.P. II, Litterae apostolicae motu proprio Misericordia Dei, nr 2.

${ }^{100}$ DPL, nr 274.

${ }^{101}$ DPL, nr 277.
} 
winni oni dołożyć starań, aby wierni, przybywający do sanktuarium z różnych stron, wracali umocnieni duchowo i zbudowani sprawowaną tam liturgią, co stanie się możliwe dzięki jej komunikatywności, prostocie obrzędowej i wierności obowiązującym przepisom liturgicznym. Ponadto będą pamiętać, że skutki wzorowo sprawowanej liturgii nie ograniczą się do samego sanktuarium, ale kapłani i wierni zaniosą dobre doświadczenie do miejsc swojego pochodzenia»" "102.

To w pierwszym rzędzie rektorzy mają troszczyć się o umożliwienie wiernym owocnego skorzystania z sakramentu pokuty przez to, że zadbają o różne elementy, które składają się na sprawowanie tego sakramentu, tzn. o miejsce sprawowania, stosowne przygotowanie do spowiedzi, jak również wybór odpowiedniego obrzędu, z częstym korzystaniem z Obrzędu pojednania wielu penitentów, z indywidualna spowiedzia $i$ rozgrzeszeniem ${ }^{103}$. Wymienieni duszpasterze winni troszczyć się o przykładne sprawowanie Eucharystii, aby „,prowadziła ona wiernych do głębokiego spotkania z Chrystusem"104, o właściwą celebrację namaszczenia chorych, często w formie wspólnotowej ${ }^{105}$, a także o sprawowanie innych sakramentów ${ }^{106}$, sakramentaliów ${ }^{107}$ oraz Liturgii Godzin ${ }^{108}$.

Kongregacja ds. Kultu Bożego i Dyscypliny Sakramentów w instrukcji Rok Eucharystii - wskazania i propozycje z 2004 r. przypomina rektorom sanktuariów, że „Rok Eucharystii bezpośrednio dotyczy także sanktuariów jako miejsc, które już ze swej natury winny obficie przekazywać wiernym środki zbawienia. Należy w nich dbać o gorliwe przepowiadanie słowa Bożego, o rozwój życia liturgicznego, szczególnie przez Eucharystię i celebrację pokuty, a także pielęgnować uznane formy pobożności ludowej" ${ }^{109}$.

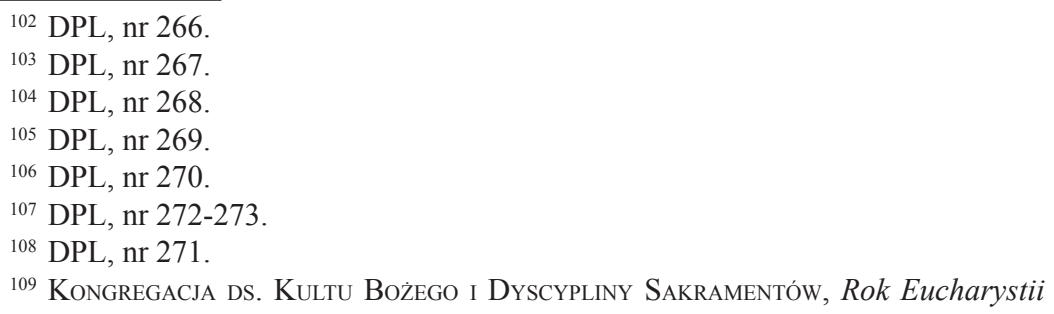


Ważnym obowiązkiem rektorów sanktuariów jest działalność na rzecz wzajemnej miłości i miłosierdzia chrześcijańskiego, gdyż „wzorcowa funkcja sanktuarium wyraża się także w świadczeniu miłości" "110.

Ponieważ „coraz bardziej utrwala się dążenie do czynienia z sanktuarium specyficznego «centrum kultury», miejsca, w którym organizuje się wykłady i konferencje, podejmuje się interesujące inicjatywy wydawnicze, realizuje się przedstawienia, koncerty, wystawy i inne działania artystyczne i literackie", stąd ważnym zadaniem kustosza jest inspirowanie i animowanie działalności kulturalnej sanktuarium, która „stanowi jakby uboczną promocję człowieka”"111.

Według definicji duszpasterstwo to ,zorganizowana działalność zbawcza Kościoła polegająca na służbie wobec człowieka"112. Aspekt organizacyjny jest więc istotny w działalności pastoralnej. Wnikliwa lektura aktualnego Kodeksu pozwala stwierdzić, że wymiar organizacyjny duszpasterstwa ma walor kanoniczny i prawodawca wyraźnie go uwypukla ${ }^{113}$. Redaktorzy Direttorio su pietà popolare e liturgia wspominają o organizowaniu duszpasterstwa odnoszącego się do czci relikwii ${ }^{114}$, o organizowaniu pielgrzymek ${ }^{115}$ czy o organizowaniu w sanktuariach obrzędu pojednania wielu penitentów z indywidualną spowiedzią i rozgrzeszeniem ${ }^{116}$. Wreszcie autorzy Wskazań i propozycji obchodu Roku Maryjnego ukazują konieczność organizowania

- wskazania i propozycje (15 października 2004), nr 36, Miesięcznik Archidiecezji Gdańskiej 49(2005), nr 4-6, s. 232-280.

110 DPL, nr 275; OPCM, nr 76; zob. X. Brossa, Régimen jurídico, s. 13, 28, 106.

${ }^{111}$ DPL, nr 276; por. OPCM, nr 73; zob. kan. 821. „Sanktuaria wyróżniają się jako cel pielgrzymek chrześcijańskich, do których przybywają także licznie turyści, bądź dla motywów kulturalnych, czy odpoczynku i ze względu na atrakcyjność religijną”. Pontificio Consiglio della Pastorale per i Migranti e gli Itineranti, Orientamenti per la pastorale del turismo, (29 giugno 2001), nr 21, Città del Vaticano 2001; zob. X. Brossa, Régimen jurídico, s. 112.

112 R. Niparko, Duszpasterstwo, w: Encyklopedia Katolicka, pod red. R. Łukaszyka, t. 4, Lublin 1995, k. 390.

${ }^{113}$ Np. kan. 770, $785 \S 1,899 \S 3,942,1254 \S 2,1064$.

114 Por. nr 237.

115 Por. nr 261.

116 Por. nr 267. 
należytego przebiegu poszczególnych etapów pielgrzymki ${ }^{117}$, w sanktuariach obrzędu pojednania wielu penitentów z indywidualną spowiedzią i rozgrzeszeniem ${ }^{118}$ czy tygodni lub dni mariologicznych ${ }^{119}$.

Przytoczone przykłady zaczerpnięte $\mathrm{z}$ reprezentatywnych dla tej kwestii dokumentów kanonicznych jasno wskazują istotną rolę wymiaru organizacyjnego duszpasterstwa Kościoła. Stąd wniosek, że jeżeli w sanktuariach to duszpasterstwo ma być wzorcowe i intensywniejsze niż w parafiach, to aspekt organizacyjny winien być tam szczególnie brany pod uwagę. Wzorowo zorganizowana posługa pastoralna jawi się więc jako prawo pątników, co implikuje zasadnicze obowiązki kustosza w tej kwestii.

Według kan. $1232 \S 2$ w statutach należy określić zwłaszcza cel i władzę rektora, prawo własności i zarząd majątkiem. Tak więc jednym z istotnych obowiązków rektora jest troszczyć się o własność i administrowanie majątkiem sanktuarium. Jest zrozumiałe, że ponieważ rektor będzie administrował majątkiem sanktuarium, stąd należy określić ten majątek wyodrębniając go od patrimonium innych podmiotów (parafia, dom zakonny, stowarzyszenie), które mogą istnieć obok sanktuarium $^{120}$.

Prawodawca domagając się uregulowania dziedziny własności i administracji majątkiem sanktuarium pragnie, aby zarząd ekonomiczny ośrodków pielgrzymkowych był dobrze określony: dobra dziedziczne, sposób zarządzania tymi dobrami i osoby odpowiedzialne za ich administrację, aby tym samym zarząd ekonomiczny nie był przeszkodą lub utrudnieniem dla realizacji celów duchowych sanktuarium ${ }^{121}$.

${ }^{117}$ Por. OPCM, nr 79.

118 Por. OPCM, nr 139.

119 Por. OPCM, nr 91.

${ }^{120}$ Por. X. Brossa, Régimen jurídico, s. 225-226. Są jednak sytuacje, że sanktuarium może być pozbawione własnego majątku o ile np. kościół sanktuaryjny, kaplica-sanktuarium należy do diecezji, do parafii, do instytutu zakonnego albo do innego podmiotu kościelnego czy świeckiego. Por. G. Feliciani, Santuario, w: Enciclopedia del Diritto, pod red. G. Landi, S. Lariccia, F. Piga, t. 41, Varese 1989, s. 301.

${ }^{121}$ Por. X. Brossa, Régimen jurídico, s. 226. 
Kwestia właściciela (posiadacza) sanktuarium (budynki), jego majątku i dzieł z nim złączonych jest wielkiej wagi, gdyż zarządzanie majątkiem, które wykonuje się w danym ośrodku pątniczym, będzie zależeć w każdym wypadku od konkretnej sytuacji prawnej w jakiej znajduje się dane sanktuarium.

Tak więc, jeśli sanktuarium należy do osoby prywatnej albo cywilnej osoby prawnej (stowarzyszenie, miasto, państwo) jego dobra będą podlegać ustawom państwowym, lecz w sprawach odnoszących się do kultu i do duszpasterstwa będą poddane władzy kościelnej, która ma także obowiązek czuwać, aby właściwie korzystano z ofiar i jałmużn. Ponad to będą miały tu zastosowanie dyspozycje o miejscach świętych, w których władza kościelna może wykonywać swobodnie swoje uprawnienia i zadania: „władza kościelna wykonuje swobodnie w miejscach świętych swoje uprawnienia i zadania"122.

Natomiast, kiedy sanktuarium jest ukonstytuowane jako kanoniczna osoba prawna publiczna albo, nie mając osobowości własnej, jest złączone z kościelną osobą prawną publiczną (diecezja, parafia, instytut życia konsekrowanego) jego majątek stanowi dobra kościelne, a zatem musi być zarządzany zgodnie z dyspozycjami księgi V KPK, jak również przez własne statuty ${ }^{123}$.

Natomiast, gdy sanktuarium miałoby osobowość kanoniczną prywatną albo należałoby do kanonicznej osoby prywatnej, jego dobra nie byłyby dobrami kościelnymi i rządziłyby się własnymi statutami, lecz władza kościelna miałaby szczególny obowiązek i prawo nadzoru nad $\operatorname{nim}^{124}$.

Zagadnienie prawa własności sanktuarium jest ściśle związane z posiadaniem albo nie przez sanktuarium kanonicznej osobowości prawnej. Posiadanie dóbr (budynki, ofiary, jałmużny) leży całkowicie w gestii sanktuarium, jeśli jest osobą prawną; w przeciwnym razie dobra te tworzą majątek odrębny od osoby tytulariusza sanktuarium ${ }^{125}$.

${ }^{122}$ Kan. 1213; por. X. Brossa, Régimen jurídico, s. 227.

${ }^{123}$ Kan. 1257 § 1; por. X. Brossa, Régimen jurídico, s. 227-228; por. J. Martín DE Agar, Comentare los cán. 1230-1234, s. 1856.

${ }^{124}$ Kan. $1257 \S 2$.

${ }^{125}$ Por. X. Brossa, Régimen jurídico, s. 228. 
Administracja dóbr osoby prawnej należy do osoby albo do organów ustalonych przez prawo partykularne, przez statuty albo przez zwyczaj prawny. W przypadku braku norm w tym względzie, administracja dóbr osoby prawnej należy do tego, kto w sposób bezpośredni rządzi osobą, do której należą dobra ${ }^{126}$. Dlatego z reguły, jeśli prawo partykularne, statuty lub prawny zwyczaj nie postanawiają czego innego, administracja dóbr sanktuarium należy, podobnie jak administracja dóbr kościoła do osoby, która stoi na czele sanktuarium, to znaczy do rektora. W tym zadaniu może być on wspierany przez radę do spraw ekonomicznych sanktuarium, pod jurysdykcją ordynariusza miejsca ${ }^{127}$. Zatem rektor sanktuarium winien informować (jeśli nie wskazuje się czegoś innego w statutach) miejscowego ordynariusza, zgodnie ze zwyczajnymi sposobami przyjętymi w zakresie kontroli innych instytucji kościelnych, o budżecie, zestawieniach wydatków itd. ${ }^{128}$.

Prawodawca ustalając treść statutów postanawia, że „w statutach należy określić zwłaszcza (praesertim) cel i władzę rektora, prawo własności i zarząd majątkiem. Słowo „zwłaszcza” (praesertim) suponuje, że także inne kwestie, również odnoszące się do zadań rektora, mogą być uregulowane w tym dokumencie, gdyż wyliczenie kan. 1232 $\S 2$ nie jest taksatywne ${ }^{129}$.

${ }^{126}$ Kan. 1279 § 1; por. X. Brossa, Régimen jurídico, s. 229.

${ }^{127}$ Por. X. Brossa, Régimen jurídico, s. 226-227; por. J. Martín de Agar, Comentare los cán. 1230-1234, s. 1853.

${ }^{128}$ Kan. 1287 § 1; por. X. Brossa, Régimen jurídico, s. 231.

${ }^{129}$ Kan. 1232 § 2 . Można np. w statucie sanktuarium uregulować sprawę kadencji kustosza: ,odpowiedzialnym za organizację życia religijnego i duszpasterstwa w Regionalnym Sanktuarium Męki Pańskiej w Imbramowicach jest Kustosz Sanktuarium, mianowany przez Biskupa Diecezjalnego. Kadencja posługi Kustosza Sanktuarium wynosi pięć lat i może być przedłużana na następne lata". Statut regionalnego sanktuarium Męki Pańskiej w Imbramowicach (30 listopada 2003), nr 4, Kielecki Przegląd Diecezjalny 80(2004), nr 1, s. 41. Można uregulować sposób sprawowania swoich czynności przez rektora: „Swoją posługę pełni Kustosz w myśl nauki Kościoła i wskazań jego dokumentów, we współpracy z dziekanem miejscowego dekanatu oraz z proboszczem parafii pod wezwaniem Św. Benedykta w Imbramowicach, w taki sposób, aby nie było jakichkolwiek niezgodności między porządkiem celebracji i nabożeństw w Sanktuarium oraz duszpasterstwem w kościele parafialnym. Statut regionalnego sanktuarium Męki Pańskiej w Imbramowicach (30 listopada 2003), nr 5, Kielecki Przegląd Diecezjalny 80(2004), nr 1, s. 41. 


\section{Wnioski}

1. Prawodawca kodeksowy postanawia, że sanktuarium winno być kierowane przez rektora (kustosza). Kan. 1232 §2 wyraźnie poleca, że w statutach należy określić „zwłaszcza władzę rektora”. Choć poprzez użycie słowa „zwłaszcza” (praesertim znaczy zwłaszcza, szczególnie) prawodawca chce powiedzieć, że nie zamierza dawać wyczerpującego katalogu materii prawnych, które winny być uregulowane w statucie, to mówiąc o władzy rektora, suponuje obowiązkowość tego urzędu w sanktuariach.

2. Rektorem sanktuarium jest kapłan, który kieruje sanktuarium zarówno w kwestiach duszpasterskich, jak i administracji majątkiem, zgodnie z prawem powszechnym i partykularnym.

3. Zależnie od okoliczności rektor sanktuarium może być jednocześnie przełożonym domu zakonnego, proboszczem, przewodniczącym kapituły itd. Tak więc określony rektor oprócz obowiązków wynikających z jego pozycji prawnej (rektor kościoła, przełożony domu zakonnego, proboszcz, przewodniczącym kapituły) ma jeszcze obowiązki wynikające $\mathrm{z}$ kan. 1234 i z ewentualnego statutu czy innych przepisów prawa, odnoszących się ściśle do sanktuariów.

4. Z reguły rektor jest mianowany swobodnie przez biskupa diecezjalnego.

5. Utrata urzędu rektora następuje według postanowienia kan. 184 §1: „urząa kościelny traci się po upływie wyznaczonego czasu, po osiągnięciu określonego prawem wieku, na skutek rezygnacji, przeniesienia, usunięcia a także pozbawienia".

6. Rektor sanktuarium winien być zdatny, czyli posiadać przymioty wymagane do tego urzędu prawem powszechnym, partykularnym lub fundacyjnym. Winien także poddać się specyficznej formacji stałej jako prezbiter i kustosz.

7. Podstawową powinnością rektora sanktuarium jest zapewnienie pielgrzymom obfitszych środków zbawienia: przez gorliwe głoszenie słowa Bożego, przez odpowiednie ożywienie życia liturgicznego, zwłaszcza przez sprawowanie Eucharystii i pokuty oraz przez kultywowanie zatwierdzonych form pobożności ludowej. 
8. Jednym z istotnych obowiązków rektora jest troszczyć się o własność i administrowanie majątkiem sanktuarium.

\section{The Position of the Shrine's Rector}

This article thoroughly presents the issue of the shrine's rector. Firstly, the term and the necessity of the rector's position are discussed. Secondly, the qualifications and the formation of the rector are shown. Finally, on the basis of the church regulations the tasks of the shrine's rector are depicted. 